Case Study

\title{
Design, Development and Evaluation of Solar Powered Aeroponic system - A Case Study
}

\author{
Naganagouda Ramalingannanavar ${ }^{1 *}$, M. Nemichandrappa ${ }^{1}$, G. V. Srinivasa Reddy ${ }^{1}$, \\ Anilkumar T. Dandekar ${ }^{1}$, J. B. Kamble ${ }^{2}$ and M. M. Dhanoji ${ }^{3}$
}

${ }^{1}$ Department of Soil and Water Engineering, College of Agricultural Engineering, University of Agricultural Sciences, Raichur- 584 104, Karnataka, India

${ }^{2}$ Department of Agricultural Engineering, College of Agriculture, Bheemarayanagudi, University of Agricultural Sciences, Raichur- 584 104, Karnataka, India

${ }^{3}$ Department of Crop Physiology, College of Agriculture, Kalaburagi, University of Agricultural Sciences, Raichur- 584 104, Karnataka, India

*Corresponding author

\section{A B S T R A C T}

\section{Keywords}

Solar power;

D.C motor pump;

Growth chamber;

Aeroponic system

Article Info

Accepted:

28 February 2020

Available Online:

10 March 2020
The solar powered aeroponic system was developed for cultivation of high valued crops. The aeroponic system was developed by using different components like SPV (Solar Photovoltaic) module, growth chamber, mister, nutrient tank, D.C pump, battery and digital timer. The system comprising a $120 \mathrm{~W}$ SPV module with 84 W D.C motor pump, main, submain, laterals and misters. The mister discharge, pump discharge, current, voltage, pump pressure and discharge of misters were tested. The mister with discharge of $7.2 \mathrm{lph}$ in the pressure range was $3.8 \mathrm{~kg} \mathrm{~cm}^{-2}$ provided by the pump. The mister spraying radius and spraying height were found to be $40 \mathrm{~cm}$ and $45 \mathrm{~cm}$ respectively. The maximum and minimum weekly relative humidity recorded inside the growth chamber were 88.1 and $84.4 \%$ at $7^{\text {th }}$ and $2^{\text {nd }}$ week respectively. Similarly, the maximum and minimum weekly relative humidity recorded outside the growth chamber were 70.4 and $58.3 \%$ at $2^{\text {nd }}$ and $7^{\text {th }}$ week respectively. The maximum and minimum weekly temperatures recorded inside the growth chamber were $21.5^{\circ} \mathrm{C}$ and $18.3^{\circ} \mathrm{C}$ at $3^{\text {rd }}$ and $4^{\text {th }}$ week respectively. Similarly, the maximum and minimum weekly temperatures recorded outside the growth chamber were $31.1^{\circ} \mathrm{C}$ and $27.4^{\circ} \mathrm{C}$ at $7^{\text {th }}$ and $2^{\text {nd }}$ week respectively during experimental period (June August 2019). Total cost of the developed aeroponic system for $4 \mathrm{~m}^{2}$ area was Rs. 30,000 including accessories.

\section{Introduction}

The global food demand is expected to grow significantly in upcoming decades due to ever increasing population. Every day, more than
200,000 people are added to the world population. Population size is projected to increase to 9.2 billion by 2050 . One of the greatest challenges is to end hunger and poverty while making agriculture and food 
systems sustainable and providing clean and fresh food for next generation is our main concerns especially for growing global population (Alexandratos and Bruinsma, 2012). About 1.44 billion ha of the world's land is arable and is under permanent cropping (FAO 1992, 1993). Most of the land that could be brought under cropping has been utilised(Borlaug and Dowswell, 1993).

Soilless culture is the technique of growing plants in soil-less condition with their roots immersed in nutrient solution (Maharana and Koul, 2004). Out of many methods of soilless cultivation, most recent and advanced system is aeroponic system. The Aeroponics means to cultivate crops without soil in an air mist environment. In this system, the crop shoot part is exposed to sunlight or artificial light. The important parameters like temperature and relative humidity inside the growth chamber are maintained at desired levels. The benefit of this method of growing is the reduction in water use at greater level compared to the traditional soil farming. With aeroponics, a farmer can grow certain types of food crops faster and larger with less water. The aeroponic culture technique is an optional device of soil-less culture in growth-controlled environments such as greenhouses. This method consists of enclosing the root system in a dark chamber and supplying a nutrient solution through mist device. This was widely used in horticultural species like lettuce (Cho et al., 1996). Lakkireddy et al., (2012) attributed the higher metabolism and growth rates in plants grown aeroponically to the increased root exposure to air which allows the plants to access more oxygen. The major advantages of aeroponic system are consumption of less water and high yield.

Solar energy is one of the renewable energy source, which is freely available at any part of the world. Now, everyone is focusing to utilize the renewable energy sources. In aeroponics, the major problem is continuous supply of power. To provide a power using solar energy, solar energy can be stored as electrical energy in batteries using PV cells. The usage of solar energy is economic, ecofriendly and farmer friendly.

The present generation is concentrating on utilization of renewable energy sources like solar energy, wind energy, geothermal energy and tidal energy. Solar energy, most popular energy source applied for aeroponic system for crop production. Continuous power supply is required for proper application of nutrients, to maintain temperature and humidity levels in desired range, to have good root physiology, shoot growth, plant growth and yield of crops.

\section{Materials and Methods}

The solar powered aeroponic system was designed and evaluation was carried out for climatological conditions of Raichur (during June - August 2019) region of Karnataka.

\section{Design and development of solar powered aeroponic system}

A solar powered aeroponic system consisted of different components. viz; Solar Photo Voltaic (SPV) module, solar charge controller, growth chamber, digital timer, D.C motor pump, battery, misters and nutrient tank.

The nutrient solution was sprayed with misters at fixed intervals. The design layout of aeroponic system is shown in Fig. 1.

\section{Power requirement for D.C pump}

The power requirement of the motor was computed using the following formula.

\section{$\mathrm{P}=\mathrm{V} \times \mathrm{I}$}

Where, 
$\mathrm{P}=$ Power $(\mathrm{W})$

$\mathrm{V}=$ Voltage $(\mathrm{V})$

$\mathrm{I}=$ Current $(\mathrm{I})$

$(\mathrm{P})=12 \times 7$

$\mathrm{P}=0.112 \mathrm{hp}=84 \mathrm{~W}$

The power rating of the pump was $12 \mathrm{~V}$ D.C and 7 Amps.

Accordingly, required capacity of SPV module was selected to supply required power.

\section{Description of components}

\section{Battery}

The battery capacity was chosen based on pump energy requirement and D.C motor rated voltage. To run the D.C motor pump, the battery was used. Based on the total amperehour required to run the D.C pump, $40 \mathrm{Ah}, 12$ $\mathrm{V}$ sealed lead acid battery was used in the experiment.

The total Ampere-hour $=40 \mathrm{Ah}$

\section{Power Supply}

The Solar Photo Voltaic (SPV) module was selected based on the power requirement of the D.C motor pump. The main parameters influencing the output of the SPV module is the solar radiation of the region and maximum sunshine hours. The $12 \mathrm{~V}, 10$ Amps and 120 W capacity SPV module was used in the experiment. Thus, power output from SPV module was calculated by recording voltage and current with respect to solar intensity. Solar charge controller was used to control the current and voltage. Based on the SPV module and battery capacity, the $12 / 24 \mathrm{~V}, 10$ Amps solar charge controller was used.

\section{Growing chamber and Pipe network}

The growing chamber consisted of an aluminium frame size of $2 \mathrm{~m} \times 1 \mathrm{~m} \times 0.6 \mathrm{~m}$ (Fig. 2) and isometric view of growing chamber is depicted in Figure 3. A black polythene sheet 300 (microns) was provided at inner side of the chamber to avoid leakage and the penetration of light into the chamber. The acrylic sheet was provided to surroundings of the growth chamber. The outlet of growth chamber and nutrient tank were connected with lateral pipe $(16 \mathrm{~mm})$ to drain excess nutrient solution back to the nutrient tank. The fabricated aeroponic growth chamber is shown in Plate 1. The nutrient tank was kept outside the growth chamber. The 300 litres capacity of rectangular loft tank was selected. The seedling holder consisted of a polystyrene sheet which is fitted at the top of the growth chamber and it supports holding of seedlings and also restrict air entry into the growth chamber. The grids were developed on the polystyrene sheet at a dimension of $15 \times 15$ $\mathrm{cm}$, and at the centre of each grid a $5 \mathrm{~cm}$ diameter hole was created to accommodate a net pot with a seedlings.

The system had two types of pipe connections, inlet and outlet pipes. The $12 \mathrm{~mm}$ diameter inletpipe was connected to pump. The $4 \mathrm{~mm}$ diameter micro tube pipe was fitted in the growth chamber up to $2 \mathrm{~m}$ length. Inside growth chamber mister was fitted on micro tube pipe to supply nutrients.

The outlet pipe of $16 \mathrm{~mm}$ was connected to nutrient tank. The misting system comprised of the nutrient tank, inlet pipes, outlet pipes and misters. Water pumped from the nutrient tank flowed through the inlet pipe to the misters for nutrient spray. In growth chamber, two microtube $(4 \mathrm{~mm})$ pipes were placed at 40 $\mathrm{cm}$ below the seedling holder. Each microtube was equipped with 10 misters, each misters praying nutrient at $360^{\circ}$ pattern(Plate 2). The parameters considered for the selection of the 
mister were spray radius, spray height, pressure and flow rate. The 20 misters of 6.5 to 7.5 litres per hour (lph) mister discharge were connected to the laterals at a spacing of $40 \mathrm{~cm}$. The number of misters per lateral was determined based on the diameter coverage in growth chamber. Thus, on each lateral 5 misters were fitted.

\section{Digital timer}

A digital timer was used for keeping specific time interval. Nutrients of plants in this system was automated with the help of digital timer. The Selec XT 546 digital timer was used for scheduling the nutrient spraying interval. The timer switches ON and OFF automatically was shown Plate 3.

\section{Construction and working of aeroponic system}

The SPV module was converting solar energy into electrical energy. The schematic circuit diagram of solar powered aeroponic system is presented in Fig. 4.

\section{Working of solar powered aeroponic system}

The incoming solar energy on SPV module was used to convert it into electrical energy and stored in a battery using solar charge controller. Solar charge controller is a device which controls the voltage and current. This energy was stored in the battery as required voltage and current. The battery provided power to D.C motor which drive the pump. The suction pressure generated from the pump driven by D.C motor lifted the nutrient solution to the laterals which were connected to submain and sprayed through the misters which are kept at the bottom of the growth chamber to the plant roots. The sprayed nutrient solution in growth chamber flowed due to gravity and collected in nutrient tank.
The process described above was repeated. The working parts of the solar powered aeroponic system is presented in the Plate 4 and Fig. 5 depicts functional components of solar power aeroponic system.

\section{Metrological indicators of temperature and relative humidity in room condition}

The weekly day time maximum temperature and relative humidity inside and outside growth chamber were recorded by using a thermo hygrometer during the testing period. The weekly day time maximum temperature and relative humidity were recorded during the day time at 1:00 pm at every seven days of interval.

\section{Results and Discussion}

The developed solar power aeroponic system was evaluated and the results are presented in Table 1. and the $120 \mathrm{~W}, 12 \mathrm{~V}$ and 10Amps capacity of SPV module was used for the experiment. The results revealed that, the current produced by the SPV module during the misting operation in aeroponic system was measured using a multimeter and current generated was recorded and it ranged from 8.2 - 8.8 Amps. The voltage generated was found to be in the range of 11.6 - 12.7. The power produced was calculated by the product of voltage and current generated in the SPV module. The power produced was recorded and ranged from $95.12-111.8 \mathrm{~W}$. The 6.5 to $7.5 \mathrm{lph}$ mister was selected for the experiment. The results revealed that, the average discharge of mister was $7.2 \mathrm{lph}$ and it was measured by volume time method. The mean operating radius of the mister was $0.4 \mathrm{~m}$ against the manufacture's specification of 0.7 $-0.9 \mathrm{~m}$ radius. The misters covered lesser radius than the manufacturer's specified radius. The mister spraying radius and spraying height were found to be $40 \mathrm{~cm}$ and $45 \mathrm{~cm}$ respectively. The $4.2 \mathrm{~kg} \mathrm{~cm}^{-2}$ D.C 
motor pump was used. The pump operating pressure was measured using a pressure gauge and it was recorded as $3.8 \mathrm{~kg} \mathrm{~cm}^{-2}$. The D.C motor diaphragm pump discharge was calculated based on volume time method. The procedure was repeated for three times and average discharge was found to be $498 \mathrm{lph}$.

Table.1 Technical evaluation of solar powered aeroponic system

\begin{tabular}{|c|l|c|c|}
\hline Sl. No. & \multicolumn{1}{|c|}{ Parameter } & Unit & Aeroponic system \\
\hline 1 & Current & Amps & $8.20-8.80$ \\
\hline 2 & Voltage & $\mathrm{V}$ & $11.60-12.70$ \\
\hline 3 & Power & $\mathrm{W}$ & $95.12-111.8$ \\
\hline 4 & Plants & No. & 156.00 \\
\hline 5 & Misters & No. & 20.00 \\
\hline 6 & Mister flow rate & $\mathrm{L} \mathrm{h}^{-1}$ per mister & 7.20 \\
\hline 7 & Total flow rate of mister & $\mathrm{L} \mathrm{h}^{-1}$ & 144.00 \\
\hline 8 & Mister spraying radius & $\mathrm{Cm}$ & 40.00 \\
\hline 9 & Mister spraying height & $\mathrm{Cm}$ & 45.00 \\
\hline 10 & Pump operating pressure & $\mathrm{kg} \mathrm{cm}^{-2}$ & 3.80 \\
\hline 11 & Pump flow rate & $\mathrm{Lph}$ & 498.00 \\
\hline
\end{tabular}

Table.2 Weekly day time maximum temperature and relative humidity in the inside and outside of the growth chamber

\begin{tabular}{|c|c|c|c|c|c|}
\hline \multirow{2}{*}{$\begin{array}{l}\text { Experiment } \\
\text { period date }\end{array}$} & \multirow{2}{*}{$\begin{array}{l}\text { Weekly } \\
\text { period }\end{array}$} & \multicolumn{2}{|c|}{ Temperature $\left({ }^{\circ} \mathbf{C}\right)$} & \multicolumn{2}{|c|}{ Relative humidity (\%) } \\
\hline & & $\begin{array}{l}\text { Inside growth } \\
\text { chamber }\end{array}$ & $\begin{array}{l}\text { Outside growth } \\
\text { chamber }\end{array}$ & $\begin{array}{l}\text { Inside growth } \\
\text { chamber }\end{array}$ & $\begin{array}{l}\text { Outside growth } \\
\text { chamber }\end{array}$ \\
\hline $\begin{array}{l}26-6-2019 \text { to } \\
2-7-2019\end{array}$ & 1 & 21.2 & 29.4 & 86.2 & 63.2 \\
\hline $\begin{array}{c}3-7-2019 \text { to } 9- \\
7-2019\end{array}$ & 2 & 20.4 & 27.4 & 84.4 & 70.4 \\
\hline $\begin{array}{c}10-7-2019 \text { to } \\
16-7-2019\end{array}$ & 3 & 21.5 & 28.6 & 85.4 & 65.2 \\
\hline $\begin{array}{c}17-7-2019 \text { to } \\
23-7-2019\end{array}$ & 4 & 18.3 & 27.7 & 86.2 & 67.8 \\
\hline $\begin{array}{c}24-7-2019 \text { to } \\
30-7-2019\end{array}$ & 5 & 19.5 & 30.6 & 86.5 & 62.5 \\
\hline $\begin{array}{c}31-7-2019 \text { to } \\
6-8-2019\end{array}$ & 6 & 18.6 & 29.6 & 87.3 & 63.6 \\
\hline $\begin{array}{l}\text { 7-8-2019 to } \\
13-8-2019\end{array}$ & 7 & 19.8 & 31.1 & 88.1 & 58.3 \\
\hline $\begin{array}{l}14-8-2019 \text { to } \\
20-8-2019\end{array}$ & 8 & 20.1 & 30.3 & 87.1 & 61.4 \\
\hline
\end{tabular}


Table.3 Investment cost for the implementation ofan $4 \mathrm{~m}^{2}$ solar powered aeroponic system

\begin{tabular}{|c|c|c|c|c|c|}
\hline $\begin{array}{l}\text { Sl. } \\
\text { No. }\end{array}$ & Particulars & Quantity & Unit & $\begin{array}{l}\text { Cost per } \\
\text { quantity }\end{array}$ & $\begin{array}{c}\text { Cost per } \\
\text { system (Rs.) }\end{array}$ \\
\hline 1 & Misters & 20.0 & No. & 20.0 & 400.0 \\
\hline 2 & Nutrient tank (300 litres) & 1.0 & No. & $2,400.0$ & $2,400.0$ \\
\hline 3 & Dripper pipes (12 mm dia) & 10.0 & $\mathrm{M}$ & 4.4 & 44.0 \\
\hline 4 & Dripper pipes (16 mm dia) & 15.0 & $\mathrm{M}$ & 6.8 & 102.0 \\
\hline 5 & Water pump & 1.0 & No. & $4,500.0$ & $4,500.0$ \\
\hline 6 & Net pot & 156.0 & No. & 2.5 & 390.0 \\
\hline 7 & Polystyrene (1m x $0.5 \mathrm{~m})$ & 8.0 & No. & 50.0 & 400.0 \\
\hline 8 & Clay balls & 2.0 & $\mathrm{~kg}$ & 200.0 & 400.0 \\
\hline 9 & Automatic timer & 1.0 & No. & $1,735.0$ & $1,735.0$ \\
\hline 10 & Battery (40 AH) & 1.0 & No. & $3,800.0$ & $3,800.0$ \\
\hline 11 & Aluminium material & 16.0 & $\mathrm{~kg}$ & 250.0 & $4,000.0$ \\
\hline 12 & Acrylic sheets & 41.0 & ft sq. & 30.0 & $1,230.0$ \\
\hline 13 & Solar panel (120W) & 1.0 & No. & $6,700.0$ & $6,700.0$ \\
\hline 14 & Solar charger controller & 1.0 & No. & 921.0 & 921.0 \\
\hline 15 & Electrical cable/wire & 50.0 & $\mathrm{ft}$ & 6.0 & 300.0 \\
\hline 16 & Lining material & 5.0 & $\mathrm{~kg}$ & 30.0 & 150.0 \\
\hline 17 & Silica gel & 1.0 & No. & 150.0 & 150.0 \\
\hline 18 & $\begin{array}{l}\text { Connector, bends, tee and } \\
\text { elbows }(12 \mathrm{~mm})\end{array}$ & 20.0 & No. & 1.8 & 36.0 \\
\hline 19 & $\begin{array}{l}\text { Connector, bends, tee and } \\
\text { elbows }(16 \mathrm{~mm})\end{array}$ & 20.0 & No. & 3.3 & 66.0 \\
\hline 20 & $16 \mathrm{~mm}$ valve & 6.0 & No. & 10.0 & 60.0 \\
\hline 21 & $12 \mathrm{~mm}$ valve & 4.0 & No. & 10.0 & 40.0 \\
\hline 22 & $4 \mathrm{~mm}$ microtube pipe & 20.0 & $\mathrm{~m}$ & 3.4 & 68.0 \\
\hline 23 & Microtube connector & 4.0 & No. & 2.0 & 8.0 \\
\hline 24 & Screws & 20.0 & No. & 2.0 & 40.0 \\
\hline 25 & Clips & 6.0 & No. & 10.0 & 60.0 \\
\hline 26 & Fabrication charges & 2.0 & No. & $1,000.0$ & $2,000.0$ \\
\hline \multicolumn{5}{|c|}{ Total } & 30,000 \\
\hline
\end{tabular}


Fig.1 Design layout of aeroponic system

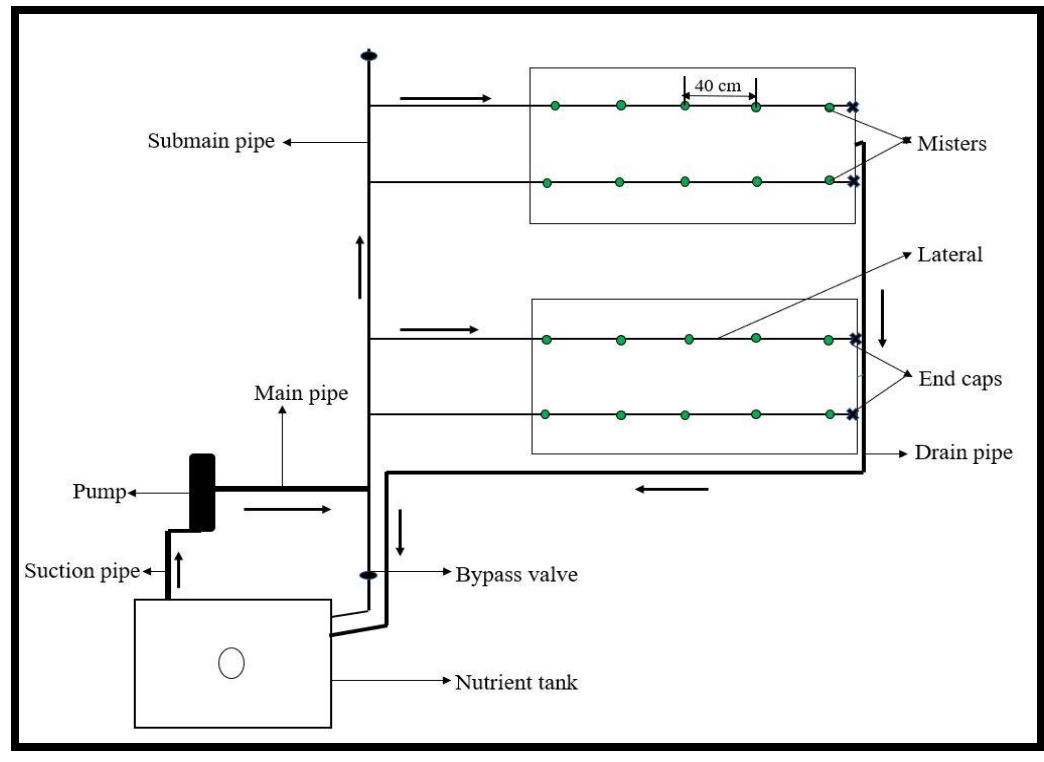

Fig.2 Design specification of growth chamber

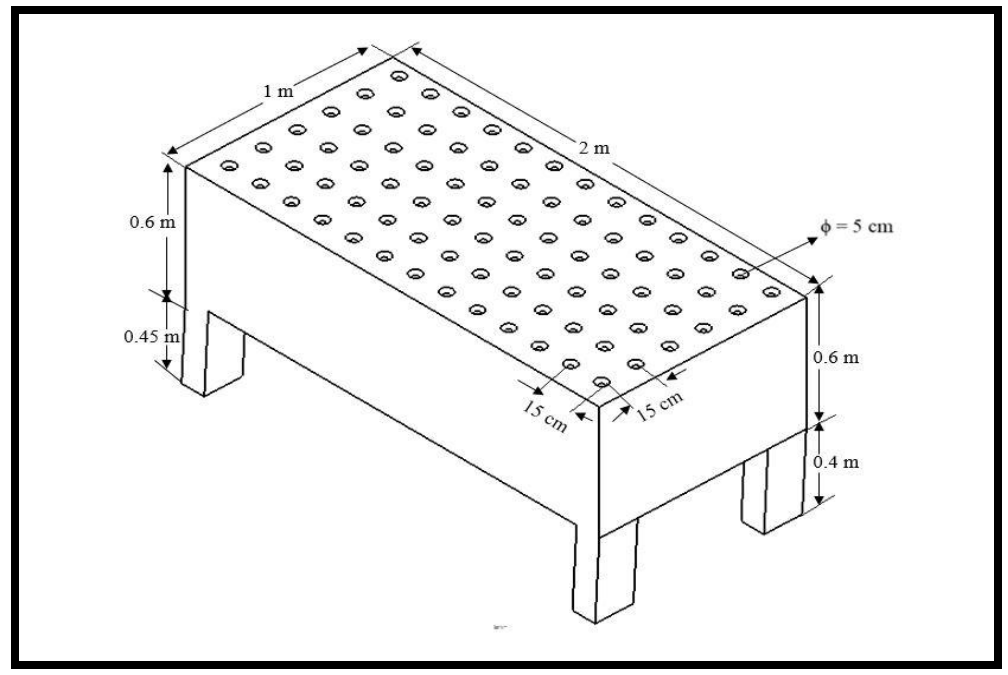


Fig.3 Isometric view of growth chamber

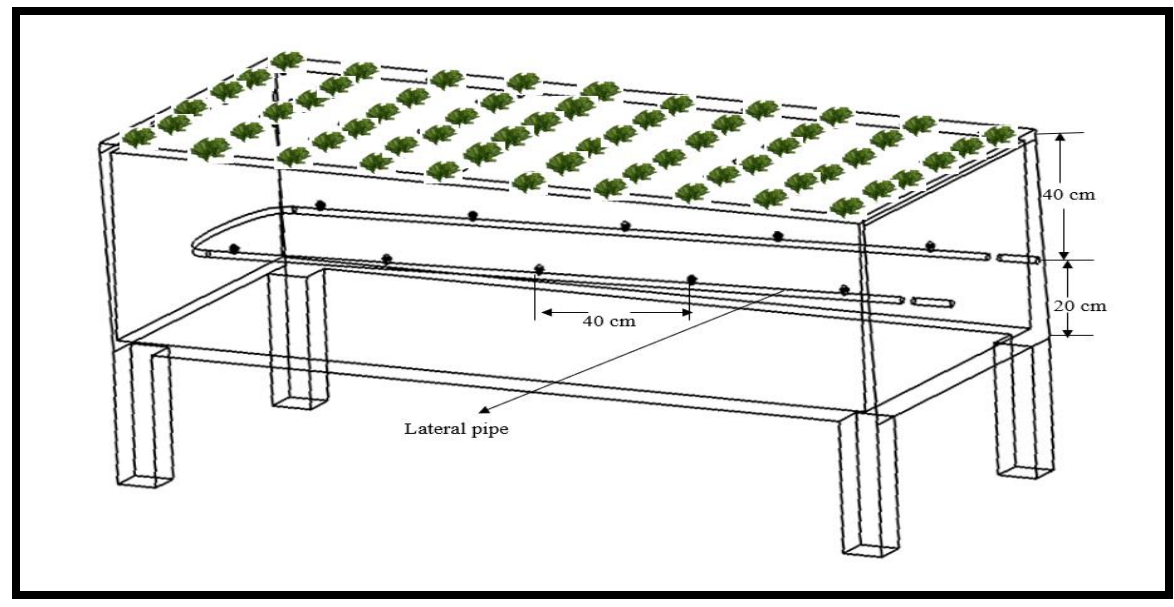

Fig.4 Circuit diagram of solar powered aeroponic system

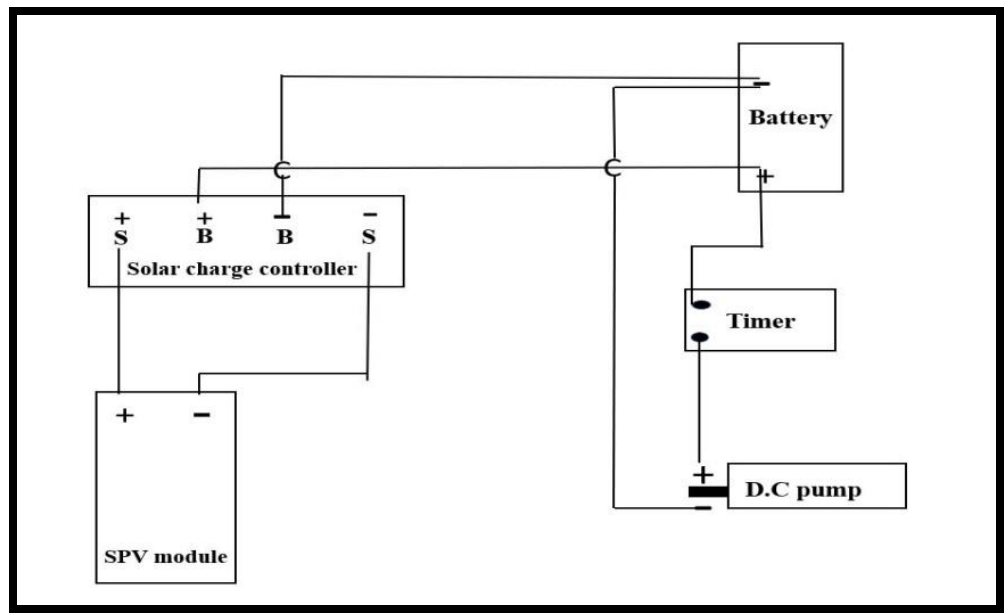

Fig.5 Functional components of solar powered aeroponic system

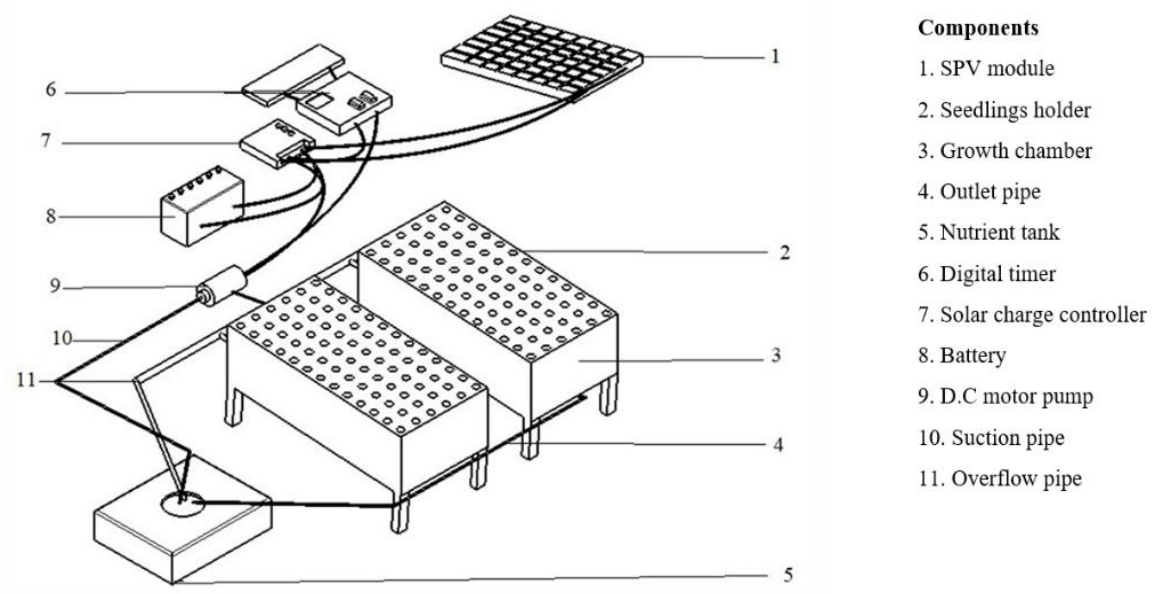


Fig.6 The temperature $\left({ }^{\circ} \mathrm{C}\right)$ variation inside and outside growth chamber

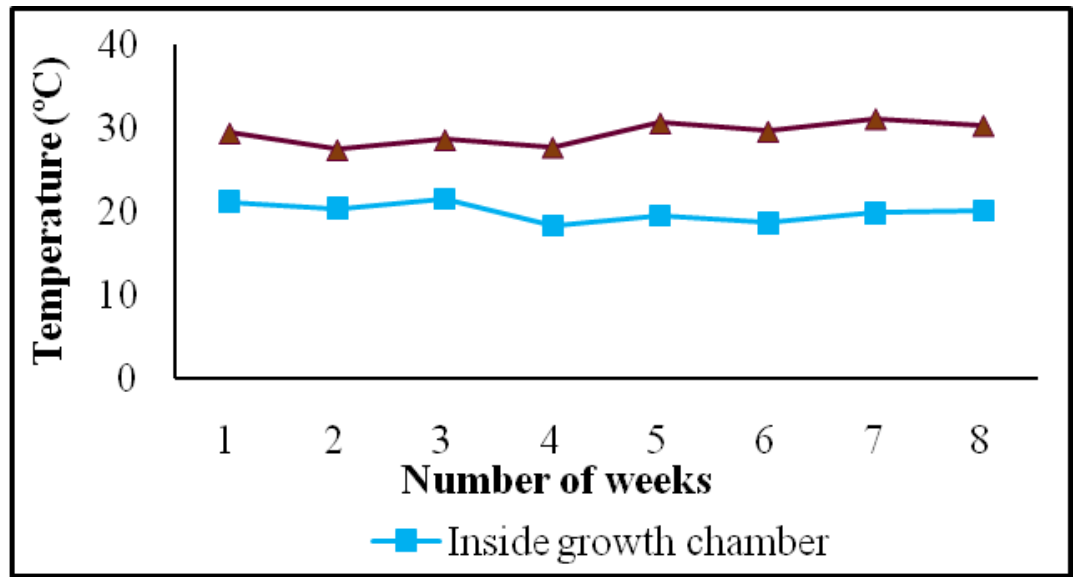

Fig.7 The relative humidity variation inside and outside growth chamber

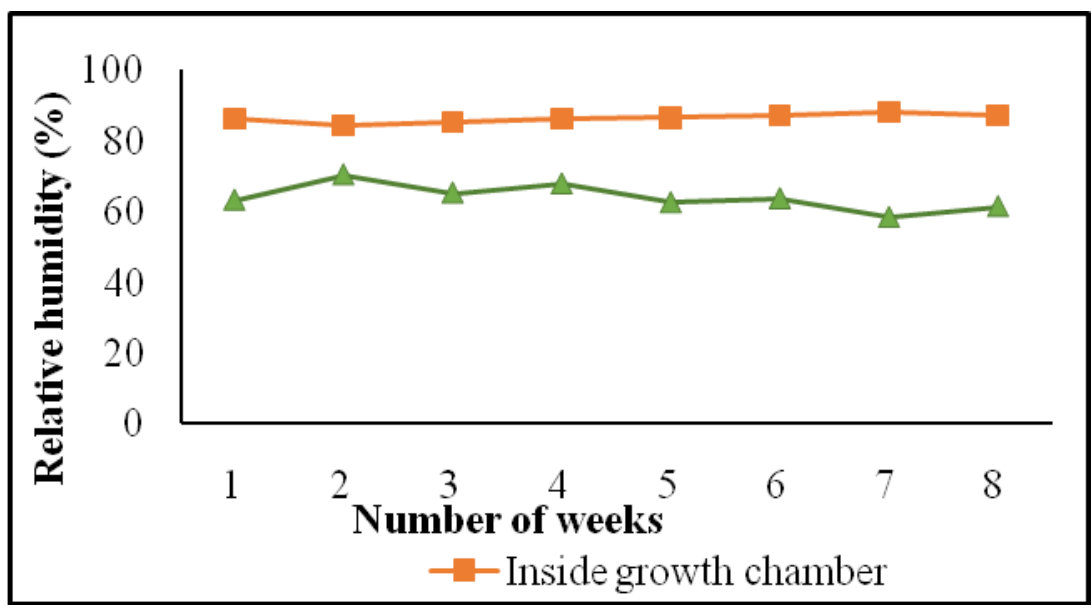

Plate.1 Fabricated aeroponic growth chamber

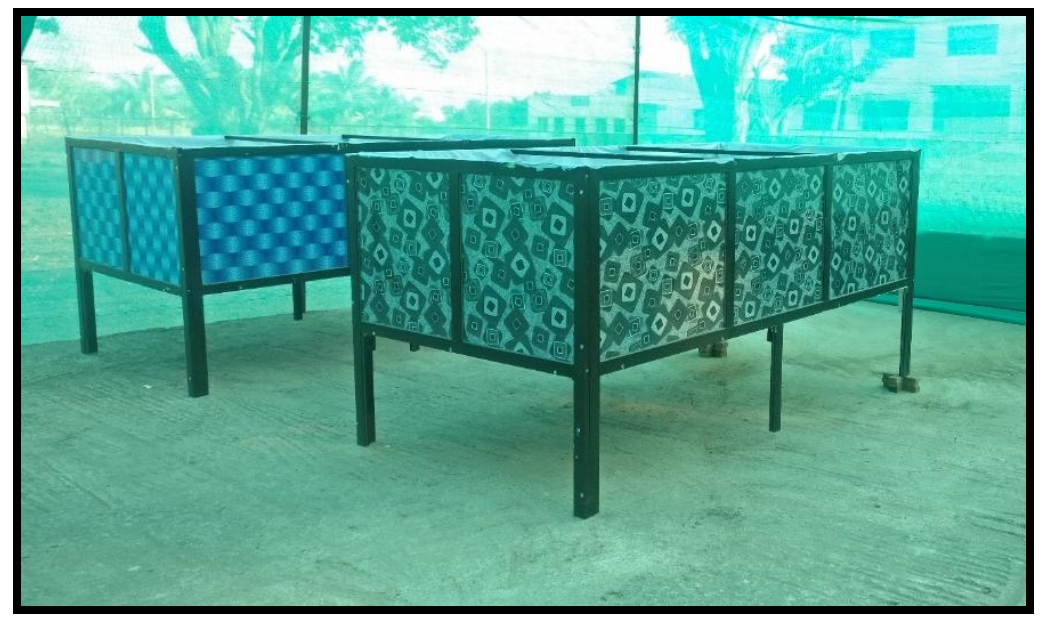


Plate.2 Misting chamber inside growth chamber

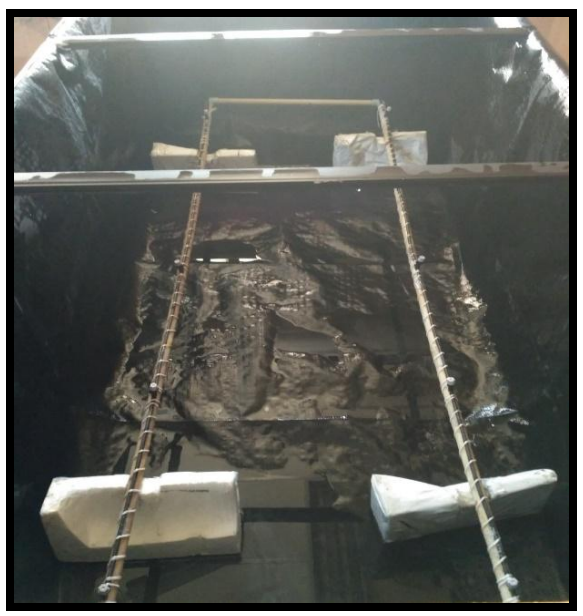

Plate.3 Automation unit in solar powered aeroponic system

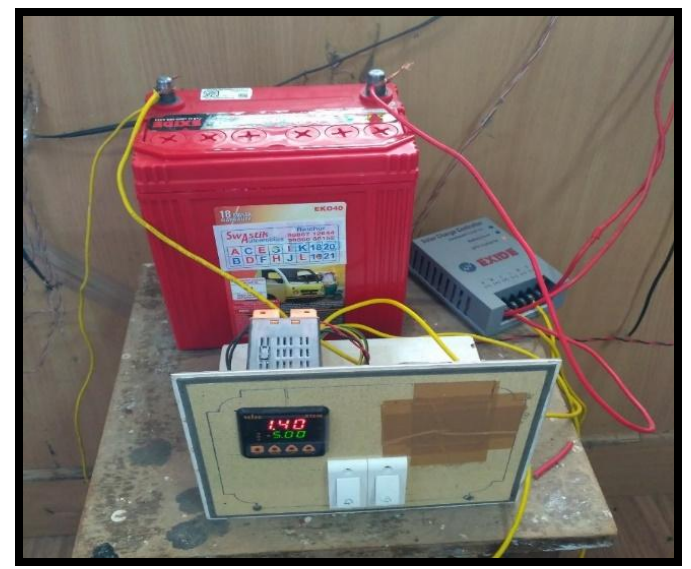

Plate.4 Working parts of solar powered aeroponic system

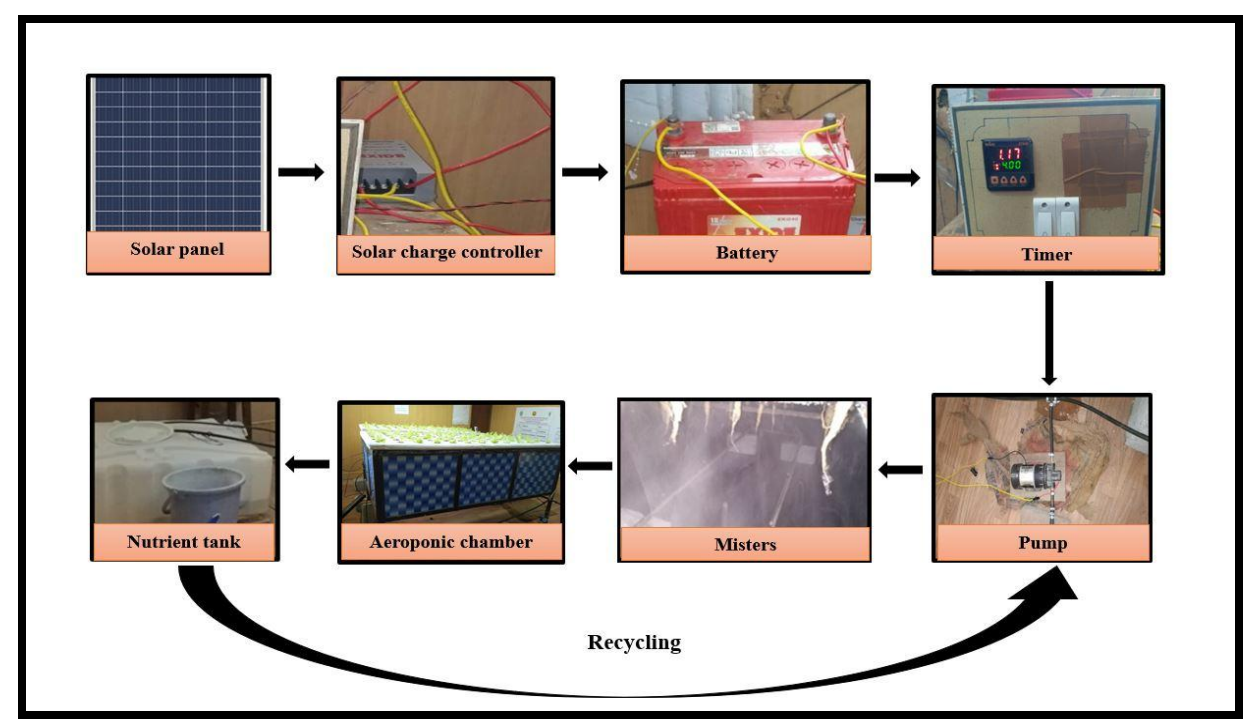




\section{Cost economics}

The investment cost of $4 \mathrm{~m}^{2}$ solar powered aeroponic system along components and cost are presented in Table 3. It was observed from the table, that total cost of the total cost of the solar powered aeroponic system for $4 \mathrm{~m}^{2}$ area has been worked out to be around Rs. 30,000.

In Conclusion, the solar powered aeroponic system was developed for cultivation of high valued crops. The technical evaluation of the system in the present case indicated that the 120W SPV module can provide 95.12 $111.8 \mathrm{~W}$ for Raichur climatic condition. The $4.2 \mathrm{~kg} \mathrm{~cm}^{-2}$ D.C. motor-pump can provide 3.8 $\mathrm{kg} \mathrm{cm}$ pressure at the delivery side with a flow rate of $7.2 \mathrm{lph}$ from each mister during the experiment. The mister spraying radius and spraying height were found to be $40 \mathrm{~cm}$ and $45 \mathrm{~cm}$ respectively. The lowest temperature and highest relative humidity were found inside the growth chamber as compared to outside the growth chamber. The investment cost for $4 \mathrm{~m}^{2}$ solar powered aeroponic system was evaluated to be Rs. 30,000. The aeroponics is the modern and innovative technology for crop cultivation without using of soil.

\section{Acknowledgement}

The authors would like to thank the College of Agricultural Engineering, Department of Soil and Water Engineering, Raichur for providing the research facilities and moral support for my work.

\section{References}

Alexandratos, N. and Bruinsma, J., 2012, World agriculture towards2030/2050: The 2012 revision FAO, Rome: ESA Working, 12, p. 3.

Borlaug, N.and Dowswell, C. R., 1993, Fertilizer: To nourish infertile soil that feeds a fertile population that crowds a fragile world. Fertilizer news, 38: 11-21.

Cho, Y. D., Kang, S. G., Kim, Y. D., Kim, K. T. and Shin, G. H., 1996, Effects of culture systems on growth and yield of cherry tomatoes in hydroponics. Journal of Agriculture Science, 38(5): 563-567.

FAO, 1992, The state of food and agriculture. Fertilizer year book, vol. 41, FAO. Rome, Italy. pp. 1-2.

FAO, 1993, The state of food and agriculture. Production year book, vol. 46, FAO. Rome, Italy. pp. 1-2.

Gagandeep Kaur., Dilip Kumar and Sukhwinder Singh., 2014, Development of an embedded circuit and a prototype bucket aeroponic system for bitter gourd production. International Journal of Computer Science and Technology, 5(3): 53-57.

Gopinath, P., Vethamoni, P. I. and Gomathi, M., 2017, Aeroponics soilless cultivation system for vegetable crops. Chemical Science Review Letters, 6(3): 838-849.

Lakkireddy, K. K. R., Kasturi, K. and Sambasiva Rao, K. R. S.,2012, Role of hydroponics and aeroponics in soilless culture in commercial food production. Research \& Reviews: Journal of Agricultural Science and Technology, 1(1): 26-35.

Maharana, L. and Koul, D.N., 2011, The emergence of hydroponics. Yojana (June), 55, pp.39-40.

\section{How to cite this article:}

Naganagouda Ramalingannanavar, M. Nemichandrappa, G. V. Srinivasa Reddy, Anilkumar T. Dandekar, J. B. Kamble and Dhanoji, M. M. 2020. Design, Development and Evaluation of Solar Powered Aeroponic system-A Case Study. Int.J.Curr.Microbiol.App.Sci. 9(03): 31023112. doi: https://doi.org/10.20546/ijcmas.2020.903.355 